\title{
Occupational injury deaths of 16 and 17 year olds in the US: trends and comparisons with older workers
}

\author{
Dawn N Castillo, Bonita D Malit
}

\begin{abstract}
Objective-To examine patterns of occupational injury deaths of 16 and 17 year olds in the United States for the three year period 1990-2, examine trends since the 1980 s, and compare fatality rates with those of older workers.
\end{abstract}

Methods-Occupational injury deaths were analyzed using the death certificate based National Traumatic Occupational Fatalities (NTOF) surveillance system. Fatality rates were calculated using estimates of full time equivalent (FTE) workers based on data from the Current Population Survey, a monthly household survey.

Results-There were 111 deaths of 16 and 17 year olds for the years 1990-2. The average yearly rate was 3.5 deaths $/ 100000$ FTE. The leading causes of death were motor vehicle related, homicide, and machinery related. All causes occupational injury fatality rates for 16 and 17 year olds were lower than for adults for 1990-2. Rates for the leading causes of death (motor vehicle related, homicide, and machinery related) were comparable or slightly higher than the rates for young and middle aged adult workers. Although rates decreased dramatically from 1980 to 1983, the decreasing trend attenuated in later years.

Conclusions-Comparisons of youth fatality rates to those of adult workers should address differences in patterns of employment, most importantly hours of work. Comparisons to narrow age groupings of adults is preferable to a single category of all workers 18 years and older. Increasing compliance with federal child labor regulations could help reduce work related deaths of youth. Other measures are needed, however, as there are many work hazards, including those associated with homicides, that are not addressed by United States federal child labor law regulations.

(Injury Prevention 1997; 3: 277 - 281)

Keywords: child labor; occupational injuries; adolescent.

Article 3 of the International Labor Organizationi C138 Convention Concerning Minimum Age for Admission to Employment, 1973 states:

'The minimum age for admission to any type of employment or work which by its nature or the circumstances in which it is carried out is likely to jeopardize the health, safety or morals of young persons shall not be less than 18 years'. ${ }^{1}$

Child labor is alcontemporary concern in both developing and industrialized countries. ${ }^{1-29}$ In general, the focus in developing countries is on human rights abuses and the general health of children, while injuries are a principal concern in industrialized countries.

Previous National Institute for Occupational Safety and Health (NIOSH) research identified 670 occupational injury deaths of 16 and 17 year olds in the United States for the years 1980 through 1989; the rate was 5.11 per 100000 full time equivalent (FTE) workers compared with a rate of 6.09 among workers 18 years and older. ${ }^{15}$ Data from 1990 through 1992 for the United States are analyzed in the present article that examines trends and rates compared with those in narrow age groups of older workers.

\section{Methods}

Fatality data are from the National Traumatic Occupational Fatalities (NTOF) surveillance system which is maintained by NIOSH. ${ }^{30}$ NTOF is a national death certificate based system in the United States with the following selection criteria: (1) the decedent was at least 16 years of age; (2) the 'injury at work?' box was checked 'yes'; and (3) an external cause of death was noted (International Classification of Diseases, ninth revision ${ }^{31}$ : E800-E999). Data were not available from Connecticut and New York City for 1992. Data from 1990 through 1991 identified only one death in these two jurisdictions. Data are not reported by industry and occupation because of the lack of useful information from the death certificate. Occupation was listed as student, unclassified, or unemployed for $85 \%$ of the deaths, and industry was listed as non-classified in $74 \%$ of the deaths.

Estimates of FTE workers, using Current Population Survey (CPS) data, ${ }^{32-34}$ were used to calculate fatality rates. The CPS is a monthly household survey from a probability sample representative of the United States civilian non-institutionalized population which collects comprehensive data on the labor force, the employed, and the unemployed. ${ }^{35}$ The CPS is conducted by the United States Census Bureau for the Department of Labor. For each age group, average hours worked were converted to FTE workers by multiplying the average number of hours worked per week by 52 weeks per year and dividing by 2000 (the 
average number of hours worked per year by a FTE worker). ${ }^{15}$ Rates of occupational injury death were calculated per 100000 FTE workers.

\section{Results}

There were 111 occupational injury deaths of 16 and 17 year olds for the three year period 1990 through 1992; the rate was 3.51/100 000 FTE. Ninety six victims were male (5.57/ 100000 FTE); 15 were female (1.04). Fifty one were 16 year olds and 60 were 17 year olds. Eighty nine victims were white (3.15/ 100000 FTE), 13 were black (5.31), and nine were of other/unknown race. Nineteen victims were reported to be Hispanic (5.86/100 000 FTE).

Table 1 Frequency and rates (deaths/100 000 FTE) of all and leading causes of occupational injury death by age group, United States, 1990-2

\begin{tabular}{|c|c|c|c|c|c|c|c|c|}
\hline \multirow{3}{*}{$\begin{array}{l}\text { Age } \\
\text { group } \\
\text { (years) }\end{array}$} & \multicolumn{2}{|c|}{ All causes } & \multicolumn{6}{|c|}{ Leading causes } \\
\hline & \multirow[b]{2}{*}{ Deaths } & \multirow[b]{2}{*}{ Rate } & \multicolumn{2}{|c|}{ Motor vehicle } & \multicolumn{2}{|c|}{ Homicide } & \multicolumn{2}{|c|}{ Machinery } \\
\hline & & & Deaths & Rate & Deaths & Rate & Deaths & Rate \\
\hline $\begin{array}{l}16-17 \\
18-19 \\
20-24 \\
25-34 \\
35-44 \\
45-54 \\
55-64 \\
65+\end{array}$ & $\begin{array}{r}111 \\
325 \\
1389 \\
3975 \\
3762 \\
2786 \\
1996 \\
1227\end{array}$ & $\begin{array}{r}3.51 \\
3.91 \\
3.87 \\
3.95 \\
3.93 \\
4.56 \\
6.39 \\
17.48\end{array}$ & $\begin{array}{r}32 \\
71 \\
309 \\
870 \\
789 \\
710 \\
470 \\
234\end{array}$ & $\begin{array}{l}1.01 \\
0.85 \\
0.86 \\
0.86 \\
0.82 \\
1.16 \\
1.50 \\
3.33\end{array}$ & $\begin{array}{r}24 \\
56 \\
243 \\
610 \\
618 \\
404 \\
257 \\
153\end{array}$ & $\begin{array}{l}0.76 \\
0.67 \\
0.68 \\
0.61 \\
0.65 \\
0.66 \\
0.82 \\
2.18\end{array}$ & $\begin{array}{r}18 \\
43 \\
151 \\
424 \\
402 \\
309 \\
310 \\
349\end{array}$ & $\begin{array}{l}0.57 \\
0.52 \\
0.42 \\
0.42 \\
0.42 \\
0.51 \\
0.99 \\
4.97\end{array}$ \\
\hline
\end{tabular}

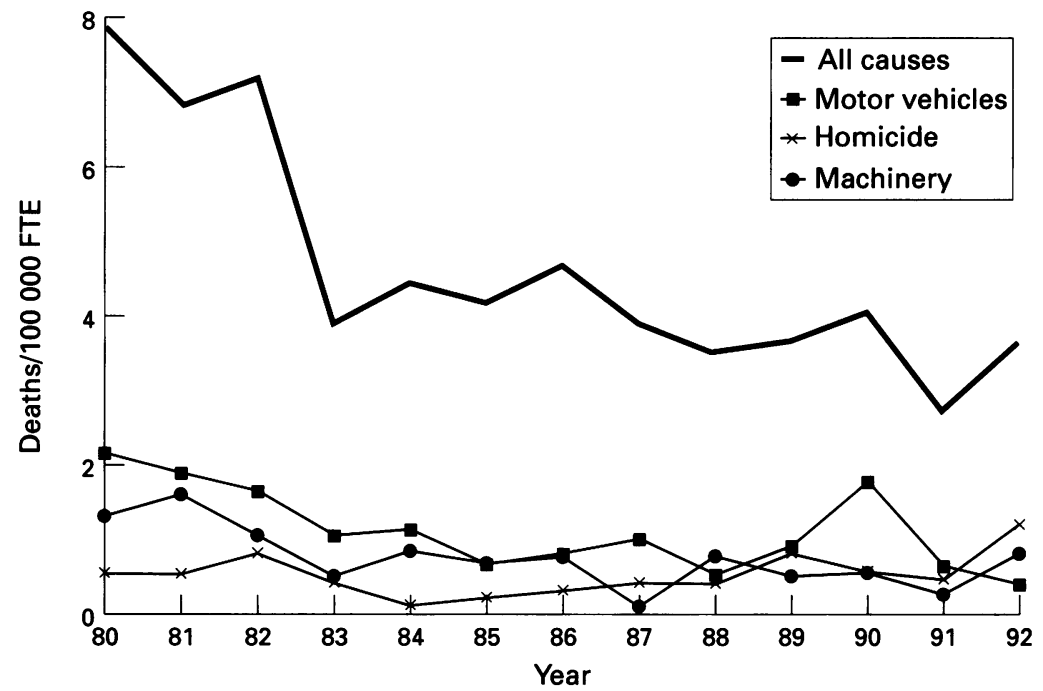

Rates for all and leading causes of occupational injury death, 16 and 17 year olds, United States, 1980-92.

Table 2 NTOF and CFOI frequency and rates of occupational injury death by age group, United States, 1992

\begin{tabular}{|c|c|c|c|c|c|}
\hline $\begin{array}{l}\text { Age group } \\
\text { (years) }\end{array}$ & $\begin{array}{l}\text { NTOF } \\
\text { Deaths }\end{array}$ & $\begin{array}{l}\text { NTOF ratel } \\
100000 \text { FTE }\end{array}$ & $\begin{array}{l}\text { CFOI } \\
\text { deaths } 39\end{array}$ & $\begin{array}{l}\text { CFOI ratel } \\
100000 \text { FTE }\end{array}$ & $\begin{array}{l}\text { CFOI ratel } \\
100000 \text { workers* }\end{array}$ \\
\hline $\begin{array}{l}16-17 \\
18-19 \\
20-24 \\
25-34 \\
35-44 \\
45-54 \\
55-64 \\
65+\end{array}$ & $\begin{array}{r}36 \\
88 \\
450 \\
1251 \\
1236 \\
921 \\
616 \\
403\end{array}$ & $\begin{array}{r}3.65 \\
3.50 \\
3.89 \\
3.81 \\
3.84 \\
4.36 \\
6.01 \\
17.17\end{array}$ & $\begin{array}{r}41 \\
92 \\
528 \\
1521 \\
1511 \\
1143 \\
751 \\
460\end{array}$ & $\begin{array}{r}4.16 \\
3.66 \\
4.56 \\
4.63 \\
4.70 \\
5.41 \\
7.32 \\
19.60\end{array}$ & $\begin{array}{r}2.00 \\
2.75 \\
4.17 \\
4.60 \\
4.73 \\
5.37 \\
6.67 \\
13.42\end{array}$ \\
\hline
\end{tabular}

*With the exception of rates for the age groups 16-17 and 18-19, rates were calculated using employment figures from the CPS 1992 which were provided in Toscano and Windau. ${ }^{39}$ Rates for age groups 16-17 and 18-19 were calculated using employment data from the CPS, 1992 published by the US Department of Labor, ${ }^{40}$ as they were not provided in Toscano and
The leading causes of death were motor vehicle related, homicide, and machinery related (table 1), accounting for two thirds of all fatalities. Motor vehicle related events were the leading cause for males and whites $\left(29^{\circ}\right.$ deaths each), whereas homicide was the leading cause for females (10 deaths) and blacks (nine). Of the 32 motor vehicle related deaths 10 of the victims were drivers, seven were passengers, and four were pedestrians (infor $\overline{\bar{w}}$ mation was unavailable for 11 victims). Amongo homicides, firearms were used in 21 of the 24 deaths. Twelve of the homicides occurred ${ }^{\text {s }}$ between 10:00 pm and 5:59 am (three occurred at an unspecified time of day) $\overrightarrow{.}$ Among the 18 machinery related deaths, sixo involved tractors and four involved forklifts. Falls, electrocution, drowning, nature/environ - ment, poisoning, suffocation, suicide, wateriv transportation, fires, air transportation, and unknown/other each accounted for six or fewer? deaths in the three year period.

Fatality rates by leading causes of death for youths and older workers for 1990-2 are also shown in table 1. The table illustrates that although all causes rates for 16 and 17 year olds are lower than for all age groups of adult workers, rates for the three leading causes of death are comparable or slightly higher than rates for young and middle aged adult workers.

Fatality rates by leading causes of death are provided for 16 and 17 year olds for the 13 yearo period 1980 through 1992 in the figure. $\frac{.}{8}$

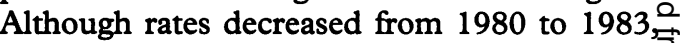
the decreasing trend attenuated in later years.

\section{Discussion}

NTOF is the most comprehensive source of information on occupational injury deaths in the United States for the years 1980 through 1991, and allows analyses of trends over time. The limitations of NTOF have been discussed previously. ${ }^{15} 30$ The primary concerns are the ability to identify work related deaths using the 'injury at work?' box, and the accuracy of 'usual' industry and occupation information on the death certificate. Research suggests that death certificates alone identify $67-90 \%$ of work related deaths, ${ }^{36}$ and that motor vehicles related deaths and homicides may be systematically missed. ${ }^{37}{ }^{38}$ One study suggested thato youth are systematically undercounted in systems which rely on medical examiners to note an 'injury at work'. This would apply too death certificates, as well as medical examiner reports. ${ }^{21}$ Although industry and occupation are fields on the death certificate, this informa $\stackrel{\text { ? }}{?}$ tion is infrequently recorded for 16 and 17 yearo olds with fatal occupational injuries. ${ }^{15}$

The Census of Fatal Occupational Injuries (CFOI), a multisource surveillance system ${ }^{\mathbb{D}}$ maintained by the United States Departmento of Labor, Bureau of Labor Statistics, provides data on occupational injury deaths beginningo in 1992. CFOI identified 41 deaths of 16 and 17 year olds in $1992,{ }^{2}$ whereas NTOF identi-? fied 36 deaths. The fatality rate based on CFOI data is 4.16 deaths $/ 100000$ FTE (table 2). Parallel calculations for adult workers demon- 
strate a similar pattern to that seen with NTOF data, with the exception of the rate for 16 and 17 year olds exceeding the rate for 18 and 19 year olds (table 2). In 1992, CFOI identified 27 deaths of youth less than 16 years of age that are not captured in NTOF. CFOI data demonstrate that the industries accounting for the most deaths of 16 and 17 year olds are retail trades, agriculture, construction, and services. $^{2}$ Additional analyses of NTOF and CFOI data for overlapping years of surveillance are needed to provide guidance on how these two systems can be used together to examine trends in United States occupational injury fatalities beginning in the 1980 s.

In the United States, there are different expectations for the protection of youths compared with adult workers. In addition to occupational safety and health regulations that mandate safe working conditions for workers of all ages, youth less than 18 years of age are afforded additional protection through federal child labor laws. ${ }^{4041}$ Included in these laws are prohibitions for youth less than 18 years of age performing non-agricultural work declared by the Secretary of Labor to be particularly hazardous (17 Hazardous Orders). ${ }^{40}$

Comparisons of fatality rates between youth and adults provides some measure as to whether society's expectation of the added protection for youth workers is being realized. There are several methodologic issues that complicate this process, however. Youth workers differ from adults on factors related to injury hazard exposure; specifically, hours of work and the types of jobs held. For example, in 1991 , youth 16 and 17 years of age worked an average of 18 hours/week compared with 28 hours/week for 18 and 19 year olds and 40 hours/week for workers 20 years and older. ${ }^{35}$ Standard presentations of occupational injury fatality rates per 100000 employed workers $^{30} 3942$ do not address differences in hours of exposure across age groups; consequently, youth rates appear on the surface to be much lower than rates for older workers (table 2).

Although the rate calculations in this paper take account of hours of work, an absence of data on the industry or occupation of fatally injured youth prevented rate comparisons between youth and adults for similar types of work. This is important because fatality rates differ across industries and occupations, and employment patterns differ between youth and adults. For example, four industry sectors (transportation, mining, construction, and agriculture) consistently have fatality rates over twice the average for all industries. ${ }^{30}$ Data for 1991, not adjusted for hours of work, show than $8 \%$ of 16 and 17 year olds worked in these four industry sectors compared with $17 \%$ of workers 18-44 years of age. ${ }^{43}$ Calculation of age specific fatality rates adjusted for hours of work by industry and occupation are needed to assess differences in risk between youth and adults for comparable types of work.

In the previous analysis of fatal youth work injuries from 1980-9, the rate for 16 and 17 year olds was compared with a rate for all workers 18 years and older. Research has demonstrated that occupational fatality rates increase with age, beginning at about 45 years, with large increases for workers 65 years and older, possibly related to decreased tolerance for injuries associated with aging (table 2)..$^{30445}$ Presentation of rates by narrow age groupings of workers, such as is done in the present analysis, allows an assessment of risks between youth and young and middle aged adults whom they more closely resemble.

Comparisons of youth and adult occupational fatality rates are also complicated from a philosophical perspective. The magnitude of difference that society would expect between youth and adult occupational fatality rates is not quantified. Is a difference of about 0.5 fewer deaths/100 000 FTE between youths and young and middle aged adults satisfactory, or should society expect a larger difference?

The leading causes of death for youths mirror those of adults: motor vehicles, homicide, and machinery. ${ }^{30}$ Deaths occur in activities that are both prohibited and permitted for youth based on current federal child labor laws in the United States. In many of the motor vehicle related deaths, the youth was the driver. Motor vehicle driving and working as an outside helper on a motor vehicle are prohibited by federal child labor laws for youth less than 18 years of age, with the exception of driving that is occasional or incidental to the work. ${ }^{40}$ Other categories of motor vehicle related deaths of youths, such as passengers, bicyclists, and pedestrians are not specifically addressed by child labor regulations.

Although death certificates provided little information about the circumstances of youth homicides in this study, previous research among workers of all ages have identified clear patterns of work related homicide. The greatest numbers and highest rates are in retail trades. ${ }^{46}$ Grocery stores and restaurants, which are common youth workplaces, ${ }^{11}$ are among the workplaces at greatest risk for work related homicides. ${ }^{46}$ About three quarters of work related homicides are associated with robberies and other crimes; firearms are the primary weapon used. Many work related homicides occur in the evening and early morning hours. Existing federal child labor laws do not address factors associated with work related homicides. For example, there are no restrictions on employment of 16 and 17 year olds in retail industries or the times of day that youth may work. ${ }^{40}$

Federal child labor laws prohibit the use of several power driven machines by youth less than 18 years of age: woodworking machines; hoisting apparatuses, metal forming, punching, and shearing machines; bakery machines; paper products machines; and, circular saws, band saws, and guillotine shears. ${ }^{40}$ Forklifts are included in prohibited hoisting apparatuses. Use of tractors by 16 and 17 year olds is prohibited only if the tractor is being used for transportation purposes on a public highway, or around certain types of work operations (mining, logging and sawmilling, and excavation).

Many have suggested that enforcement of 
existing federal child labor laws is insufficient and should be strengthened. ${ }^{11} 2124$ 47-51 Additionally, there are groups of working children and adolescents who are not subject to the federal child labor laws, including those working for firms with less than $\$ 500000$ in annual sales or business, employees with no involvement in interstate commerce, and children of sole proprietors and farmers. ${ }^{4041}$

Thus, other avenues for prevention, besides regulation, need to be pursued. Recommendations for the prevention of work related homicide serve as an example on how changes in the workplace and how work is done may decrease injury risk. Potential prevention strategies include: cash handling policies that minimize the amount of money that would be accessible through a robbery; good lighting; environmental designs that make cash exchange areas visible to the public; increased staffing; and training in recognition of potential hazards associated with violence and safe work practices. ${ }^{46}$ Rollover protective structures on tractors are an example of an engineering strategy for reducing work related deaths; however, the appropriateness of any tractor use by youths is debatable. ${ }^{505253}$ Available data suggest that youth do not routinely receive training on hazards in their work environment and safe work practices. ${ }^{1754-56}$ Employers should be encouraged to provide youth with injury prevention training. ${ }^{952}$ Providing youths with information on occupational safety and health through other means, such as through general education in schools, may also be effective. ${ }^{1757}$

\section{Implications for prevention}

There are many interested parties who can play a part in preventing occupational injury deaths of youths. Employers need to know, and comply with, child labor and occupational safety and health laws; provide a safe and healthful work environment; ensure that youths recognize hazards and are competent in safe work practices; and provide appropriate supervision. ${ }^{9}$ Parents should be encouraged to take an active role in the child's employment decisions, taking into consideration available information on workplace hazards and risks. Safety should be a principal concern when educators approve work permits, and endeavor to prepare students for the world of work and provide or facilitate work experience. Injury control professionals could incorporate information on workplace hazards into their efforts focused on adolescents. ${ }^{58}$ Medical providers who sign work permits should be familiar with child labor laws. Medical providers should also take work histories, record work relatedness of injuries on medical records, including death certificates, and incorporate information about workplace hazards into prevention messages delivered during routine visits. Equipment manufacturers should clearly label equipment that is not appropriate for youths and consider incorporating safety features for the less skilled youth worker. Insurers may be able to provide financial incentives for ensuring that youths are provided with job safety training, and that youths are not involved in prohibited activities. Job programs should provide knowledge and skills that will keep youths safe and healthy at work.

NIOSH has recently funded community. based demonstration projects at three sites in the United States. ${ }^{559}$ These demonstration projects are developing and testing innovative materials and methods that can be used by community members for informing young $\widehat{\Phi}_{\overparen{Q}}$ people and adults about workplace hazards, and promoting safe and healthful working ${ }^{\infty}$ experiences for working children and adoles- $\vec{O}$ cents. Forthcoming information from these $\vec{\overrightarrow{ }}$ projects can guide similar efforts in other $\stackrel{\omega}{\circ}$ communities.

US Department of Labor, Bureau of International Labor Affairs. By the sweat and toil of children. Volume II: the use of child labor in US agricultural imports and forced and bonded 0 child labor. (A report to the Committee on Appropriations, US Congress.) Washington, DC: US Department of Labor, Bureau of International Labor Affairs, 1995

2 Derstine B. Job-related fatalities involving youths, 19921995. Fatal workplace injuries in 1995: a collection of data and analysis. Washington, DC: US Department of Labor, $\mathbb{D}$ and analysis. Washington, DC: US Department of Labor,

3 Centers for Disease Control and Prevention. Work-related injuries and illnesses associated with child labor-United States, 1993. MMWR 1996; 45: 464-8.

4 Brooks DR, Davis LK. Work-related injuries to Massachusetts teens, 1987-1990. Am F Ind Med 1996; 29: 153-. 60.

5 International Labour Office. Child labour: what is to be done? (Document for discussion at the Informal Tripartite Meeting at the ministerial level.) Geneva, Switzerland: International Labour Organization, 1996.

6 Workers' Compensation Board of British Columbia. WCB safety campaign aims to protect young workers. Prevention $\bar{D}$ at Work 1996; 2 (4): $1-2$.

7 Worksafe Australia. Campaign for new workers. Worksafe $\vec{\overrightarrow{ }}$ News 1996; 11 (1): $9-16$.

8 Miller M. Occupational injuries among adolescents in Washington state, 1988-1991: a review of workers' compensation? data. Olympia, Washington: Safety and Health Assess- $\overline{0}$ ment and Research for Prevention, Washington Department of Labor and Industries, 1995. (Technical report No 35-1-1995.)

9 Castillo DN. NIOSH alert: request for assistance in preventing deaths and injuries of adolescent workers. Cincinnati, $\mathrm{OH}: \mathrm{O}$ US Department of Health and Human Services, 1995 . NIOSH publications, DHHS (NIOSH) publication No 95-125.)

10 Cooper SP, Rothstein MA. Health hazards among working children in Texas. South Med $\mathcal{F} 1995 ; 88$ : 550-4.

11 Children's Safety Network at Education Development Center, Inc and Massachusetts Occupational Health Surveillance Program. Protecting working teens: a public. health resource guide. Newton, MA: Education Development Center, 1995.

12 Brison RJ. Fatal farm injuries in Ontario, 1984 through 1992. Can $\mathcal{f}$ Public Health 1995; 86: 246-8.

13 Mandryk J, Harrison J. Work-related deaths of children and adolescents in Australia, 1982-1984. Aust f Public Health 1995; 19: 46-9.

14 Parker DL, Carl WR, French LR, Martin F. Characteristics of adolescent work injuries reported to the Minnesota of abor and Industry. Am $f$ Public Health ${ }^{\circ}$ 1994; 84: 606-11.

15 Castillo DN, Landen DD, Layne LA. Occupational injury deaths of 16- and 17-year-olds in the United States. Am $7 \mathrm{WW}$ Public Health 1994; 84: 646-9.

16 Layne LA, Castillo DN, Stout N, Cutlip P. Adolescent occupational injuries requiring hospital emergency de-e partment treatment: a nationally representative sample. Am F Public Health 1994; 84: 657-60.

17 Bush D, Baker R. Young workers at risk: health and safety. education and the schools. Berkeley, CA: University of California at Berkeley, 1994.

18 US Department of Labor, Bureau of International Labor Affairs. By the sweat and toil of children: the use of child labor in American imports. (A report to the Committee on $\overparen{\mathbb{D}}$ Appropriations, United States Congress.) Washington, $\varrho$ Appropriations, United States Congress.) Washington, DC: US Department

19 Feingold E, Wasser J. Walk-through surveys for child labor. 8 Am f Ind Med 1994; 26: 803-7.

20 Belville R, Pollack S, Godbold JH, Landrigan PJ. Occupational injuries among working adolescents in New York State. $\mathcal{F A M A}$ 1993; 269: 2754-9.

21 Dunn KA, Runyan CW. Deaths at work among children and adolescents. Am $\mathrm{F}$ Dis Child 1993; 147: 1044-7.

22 Banco L, Lapidus G, Braddock M. Work-related injury among Connecticut minors. Pediatrics 1992; 89: 957-60. 
23 Heyer NJ, Franklin G, Rivara FP, Parker P, Haug JA. Occupational injuries among minors doing farm work in Washington State:

24 Suruda A, Halperin $W$. Work-related deaths in children. Am $\mathcal{F}$ Ind Med 1991; 19: 739-45.

25 Glor ED. Survey of comprehensive accident and injury experience of high school students in Saskatchewan. Can f Public Health 1989; 80: 435-40.

26 Schober SE, Handke JL, Halperin WE, Moll MB, Thun MJ. Work-related injuries in minors. Am $\mathcal{F}$ Ind Med 1988; 14: $585-95$.

27 Moorehead C. School age workers in Britain today. London, UK: Anti-Slavery Society, 1987. (Child labor series: No 8.)

28 World Health Organization. Children at work: special health risks. Geneva, Switzerland: World Health Organization, 1987. (WHO technical report series 756.)

29 State of Wyoming. Characteristics of youth occupational injuries and illnesses 1979-1983. Cheyenne, WY: Wyoming Department of Labor and Statistics, 1984.

30 Jenkins EL, Kisner SM, Fosbroke DE, et al. Fatal injuries to workers in the United States, 1980-1989: a decade of surveillance: national profile. Washington, DC: US Government Printing Office, 1993. (DHHS (NIOSH) No 93108.)

31 World Health Organization. International classification of diseases: manual on the international statistical classification of diseases, injuries, and causes of death. 9th Revision. Geneva, Switzerland: World Health Organization, 1977.

32 Current Population Survey [database]. Washington, DC: US Department of Labor, Bureau of Labor Statistics [cited 19 March 1996]. December 1992 base tables. CPSPR2 Table 27B. Persons at work by hours of work, age, sex, race, and Hispanic origin. 1992 annual averages. Revised 1996 February 06.

33 Current Population Survey [database]. Washington, DC: US Department of Labor, Bureau of Labor Statistics [cited 19 March 1996]. December 1991 base tables. CPSPR2. Table 27B. Persons at work by hours of work, age, sex, race, and Hispanic origin. 1991 annual averages. Revised 1995 November 01.

34 Current Population Survey [database]. Washington, DC: US Department of Labor, Bureau of Labor Statistics US Department of Labor, Bureau of Labor Statistics CPSPR2. Table 27B. Persons at work by hours of work, age, sex, race, and Hispanic origin. 1990 annual averages. Revised 1995 October 11.

35 US Department of Labor, Bureau of Labor Statistics. Employment and earnings. Washington, DC: US Government Printing Office, January 1992.

36 Stout N, Bell CA. Effectiveness of source documents for identifying fatal occupational injuries: a synthesis of studies. Am $\mathcal{F}$ Public Health 1991; 81: 725-8.

37 Russell J, Conroy C. Representativeness of deaths identififed through the injury-at-work item on the death certificate: implications for surveillance. Am $f$ Public Health 1991; 81: 1613-8.

38 Colorado Department of Health. Colorado population-based occupational injury and fatality surveillance system report, 1982-1984. Denver, CO: Health Statistics Section, Colorado Department of Health, 1988

39 Toscano G, Windau J. Fatal work injuries: results from the 1992 national census. Fatal workplace injuries in 1992: a collection of data and analysis. Washington, DC: US Department of Labor, Bureau of Labor Statistics. Report 870, 1994: 1 - 10

40 US Department of Labor. Child labor requirements in nonagricultural occupations under the fair labor standards act. Washington, DC: US Department of Labor, Employments Standards Administration, Wage and Hour Diviments Standards Administration, Wag

41 US Department of Labor. Child labor requirements in agriculture under the fair labor standards act. (Child Labor Labor, Employment Standards Administration, Wage and Hour Division, 1990. (WH publication 1295.)
42 Toscano G, Windau J. National census of fatal occupational injuries, 1995. Fatal workplace injuries in 1995: a collection of data and analysis. Washington, DC: US Department of fabor, Bureau of Labor Statistics. Report 913, 1997: 112.

43 Current Population Survey [database]. Washington, DC US Department of Labor, Bureau of Labor Statistic [cited 13 September 1996]. December 1991 base tables. CPSPR2. Table 18. Employed persons by major industry, sex, race, Hispanic origin, and age. 1991 annual averages. Revised 1995 November 01 .

44 Kisner SM, Pratt SG. Occupational fatalities among older workers in the United States: 1980-1991. F Occup Environ Med 1997; 39: 715-21.

45 Personick E, Windau JA. Characteristics of older workers' injuries. Fatal workplace injuries in 1993: a collection of data injuries. Fatal workplace injuries in 1993: a collection of data and analysis. Washington, DC: US Department

46 Jenkins EL. Current intelligence bulletin 57: violence in the workplace: risk factors and prevention strategies. Cincinnati, $\mathrm{OH}$ : US Department of Health and Human Services, 1996. (NIOSH publications, DHHS (NIOSH) Publication No 96-100.)

47 Whittaker WG. Child labor and public policy: legislative and administrative issues. Washington, DC: Congressional Research Service, the Library of Congress, Order Code IB94057, 9 February 1996.

48 Committee on Environmental Health. The hazards of child labor. Pediatrics 1995; 95: $311-3$.

49 Pollack SH, Landrigan PJ, Mallino DL. Child labor in 1990: prevalence and health hazards. Annu Rev Public Health 1990; 11: $359-75$.

50 National Committee for Childhood Agricultural Injury Prevention. Children and agriculture: opportunities for safety and health. Marshfield, WI: Marshfield Clinic, 1996

51 US General Accounting Office. Child labor: characteristics of working children. Washington, DC: US General Accounting Office, 1990. GAO/HRD-90-116.

52 NIOSH. Comments of the National Institute for Occupational Safety and Health on the Department of Labor/Wage and Hour Division advance notice of proposed rulemaking on child labor regulations, orders and statements of interpretation. Cincinatti, OH: US Department of Health and Human Services, Public Health Service, Centers for Disease Services, Public Health Service, Centers for Disease tional Safety and Health, Division of Standards Develtional Safety and Health, Division of Stand

53 National Safety Council Agricultural Division. Council approves policy on childhood risks. Itasca, IL: National Safety Council, Agricultural Division Newsletter, March April, 1996.

54 Human Resources Development Canada. Occupational safety and health: a factor of productivity/healthy workplace ... healthy business! - Article 23.2. Text available on the internet: http://gala.ccohs.ca/naosh/wk23-2en.htm, May 1997.

55 Cohen LR, Runyan CW, Dunn KA, Schulman MD. Work patterns and occupational hazard exposures of North patterns and occupational hazard exposures of North 2: $274-7$.

56 Knight EB, Castillo DN, Layne LA. A detailed analysis of work-related injury among youth treated in emergency departments. Am F Ind Med 1995; 27: 793-805.

57 American Public Health Association. Protection of child and adolescent workers-policy statement adopted by the governing council of the American Public Health Association, November 2, 1994. Am f Public Health 1995; 85: 440-2.

58 NIOSH. NIOSH special hazard review: child labor research needs: recommendations from the NIOSH child labor working team. Cincinnati, OH: US Department of Health and team. Cincinnat, OH: Us Department of Health and Human Services, Public Health Service, Centers for lication No 97-143.)

50 Rivara FP, Roberts I, Bass D, et al. Child and adolescent injury control activities: reports from the field. Injury Prevention 1996; 2: 178-80. 